\title{
DIVERSITY AND ABUNDANCE OF SOIL-BORNE PATHOGENIC FUNGI IN VARIOUS LAND-USE SYSTEMS IN SUMBERJAYA, LAMPUNG
}

\author{
Joko Prasetyo ${ }^{1}$ and Titik Nur Aeny ${ }^{1}$
}

\begin{abstract}
Diversity and abundance of soil-borne pathogenic fungi in various land-use systems in Sumberjaya, Lampung. This study was aimed to investigate the effects of land use systems on diversity and abundance of soil-borne pathogenic fungi. Soil samples were collected from Sumberjaya area, West-Lampung, during October 2004. A total of 88 soil samples were collected from seven land use systems: (1) undisturbed forest, (2) disturbed forest, (3) shrub, (4) polyculture coffee, (5) monoculture coffee, (6) food crop, and (7) horticulture crop. The soil samples were laboratory analyzed to isolate and enumerate viable fungal propagules using bioassay procedure by a modified most probable number technique. The results of the study showed that land-use systems had different impacts on diversity and abundance of soil-borne pathogenic fungi. The diversity declined in non-agricultural systems from undisturbed forest to disturbed forest, shrub, and polyculture coffee, and then increased in agricultural systems from polyculture coffee to monoculture coffee, and food crop. In horticulture crop, however, the diversity was lower than that of in food crop system. The abundance had a similar trend except for horticulture crop that showed the highest population. The occurrence of soil-borne pathogens was different across land use systems. Fusarium spp. dominated all land uses, except in shrub that was dominated by Curvularia spp. Botryodiplodia spp. occurred in undisturbed and disturbed forests, decreased in shrub and then disappeared in other land uses. The occurrence of Phytophthora spp. and Pythium spp. was limited in undisturbed and disturbed forest, then disappeared in shrub, in polyculture and monoculture coffee, but increased significantly in food crops. Rhizoctonia sp. only occurred in undisturbed forest.
\end{abstract}

Key words : land use systems, soil-borne pathogen, diversity, abundance

\section{INTRODUCTION}

Soil is the reservoir of heterogeneous microbes. There are saprophytes, parasites, and facultative microbes in the soils. They interact each other and build an equilibrium in the soil. The type of genera and their abundance are significantly affected by the vegetation growth above ground. Human activities started from land clearing have been considered as intervention that causes some conversions of land use systems from a natural undisturbed forest through an intensive agriculture system. The changes of land-use systems affect the types and number of above ground vegetation (Gillison et al., 2003). The loss of single plant results in the elimination of up to 15 other species depended on the plant (Schumann, 1991)

In a natural forest, the biological diversity and population of above-ground vegetation is very high, so as the soil microbes. The vegetation serves as a huge food supply for different kinds of above-ground as well as below-ground microbes, including soilborne microbes. On the contrary, in an agricultural land- use system, there are intensive human activities that bring many kinds of inputs, and a modern agriculture is implying monoculture system. Cook
(1984) has hypothesized that when organic materials were incorporated into the soil, crop losses due to soilborne plant pathogens would be minimized if no one crop species was grown in the same field more than once every five years.

Many articles reported that the soil of natural forest has suppressive characters against plant pathogens (Tsao, 1969; Broadbent \& Baker, 1974). The suppressiveness is mainly due to the presence of antagonist microbes such as Trichoderma viride and Glyocladium virens (Mao et al., 1997) and Pseudomonas fluorescence (Broadbent \& Baker, 1974). The initially high number and type of microbes responsible in suppressiveness in the natural forest are suspected to decrease along with the conversions of land-use systems. And the decrease of antagonist microbe population has given a big chance for the pathogenic microbes to grow and develop in the new intensive land-use system.

This study was conducted to investigate the effects of seven land-use systems on the genus number of potential phytopathogenic fungi and their abundance in the soil.

\footnotetext{
${ }^{1}$ Lecturer at Plant Protection Department, Faculty of Agriculture, University of Lampung

J1 Prof. Sumantri Brojonegoro No. 1 Bandar Lampung 35145 Indonesia, email : jprasetyo04@yahoo.com
} 


\section{MATERIALS AND METHODS}

The study was conducted from October 2004 to April 2005. The soil samples were collected from Bodong Jaya, Sumberjaya area, and Lampung, Indonesia during October 2004. The area has seven land-use systems including undisturbed forest (Forest Less Intensive $=$ FLI), disturbed forest (Forest Intensive = FI), shrub and grassland (Shrubs), shaded/polyculture coffee (Tree Based Less Intensive $=\mathrm{TBLI})$, monoculture coffee $($ Tree Based Intensive $=$ TBI), food crops (Crop Based Less Intensive $=$ CBLI), vegetable/horticulture crop (Crop Based Intensive = CBI). The samples were collected from total of 88 sampling points from the seven land-use systems that selected by grid system (Susilo \& Karyanto, 2005). From each sampling point, as much as 12 soil cores were collected from two circles of $6 \mathrm{~m}$ and $12 \mathrm{~m}$ diameter, composited, and bagged for laboratory analyses. The sampling method was described in Susilo \& Karyanto (2005).

In this study, isolation and enumeration of viable fungal propagules were done using the mostprobable number technique (Vincent, 1970) that was modified. This technique combines a host bioassay with a soil dilution. In this case, instead of the whole seedling materials usually used as the host bioassay, we used plant segments as the bait of soil-borne fungal pathogens. This approach is commonly used to estimate more accurately the amount of infective inoculums present in soil. The method involves testing diluted samples of soil to determine whether the organism is present or not. The proportion of samples that contain the organisms, as determined in a bioassay by host symptoms, can be related to the number of infective propagules in a given volume of the original soil (Cambell \& Madden, 1990). The fungi grown in an agar plate were then identified to genus level.

\section{Enumeration of Fungal Pathogen Population by} Modified Most Probable Number. Instead of using the whole seedlings, we use plant segments (apple fruits, carrot tubers, and rice straw) as the infection indicator or as the bait. Enumeration of viable propagules of soil-borne pathogen is conducted in fourfold dilution as follows: a gram of soil sample is mixed with three gram of sterilized sands to obtain $4^{1}$ dilution (mixture) to bring a total of 4 gram mixture. Two gram of the $4^{1}$ dilution is inoculated to four sites of the sterilized indicator plant segments, $0.5 \mathrm{~g}$ mixture for each site. Next, $1 \mathrm{~g}$ of $4^{1}$ soil mixture is added to another $3 \mathrm{~g}$ of sterilized sands to obtain $4^{2}$ mixture. Two gram of $4^{2}$ soil mixture is inoculated to four sites of bait. This procedure was repeated to obtain $4^{4}$ soil mixture.

The inoculated bait was examined for the manifested symptoms. The microorganism involved was isolated from each symptom and identified. The estimate count of soil borne fungal pathogen per gram of soil is given by the formula as follow:

$$
\mathrm{X}=\frac{\mathrm{m} \cdot \mathrm{d}}{\mathrm{v} \cdot \mathrm{g}}
$$

Where $\mathrm{m}=$ likely number of mixing 1 in the series (from table); $d=$ the first mixing; $v=$ volume of soil for inoculation at each site; $g=$ weight (volume) of soil sample.

\section{RESULTS AND DISCUSSION}

Diversity of soil-borne fungal plant pathogens. The results of the survey showed that the number of soil borne fungal genera in non agricultural system declined from undisturbed forest to disturb forest, shrub and grass land, and coffee shaded (polyculture coffee), but in agricultural system it increased from coffee shaded to monoculture coffee and food crop (Figure1). In food crop, the diversity of fungal pathogens was lower than that of on horticulture crop. The decline of soil borne fungal pathogen genera in non agricultural system was believed to be due to the decrease of the number and kind of host plants growing in the area and the micro climates on the land use systems. It is known that every kind of host plant has a series of associated pathogens. Shurtleff and Avere III (1997) stated that the possible number of plant disease in the world is the combination between number of plant kind and number of plant pathogen kind. Thus the decrease of number genera is directly related to the number of host plants.

The increase of soil-borne pathogenic fungi in agricultural system is suspected to be related to other factors. Human involvement may have has increased the number of plant pathogenic fungi through the use of chemicals, soil tillage, and introduced crop. The use chemicals in the long term weaken the role of antagonist and other beneficial microbes and increase the role of plant pathogens. In the long term intensive tillage forms hard pan and then increase the incidence 


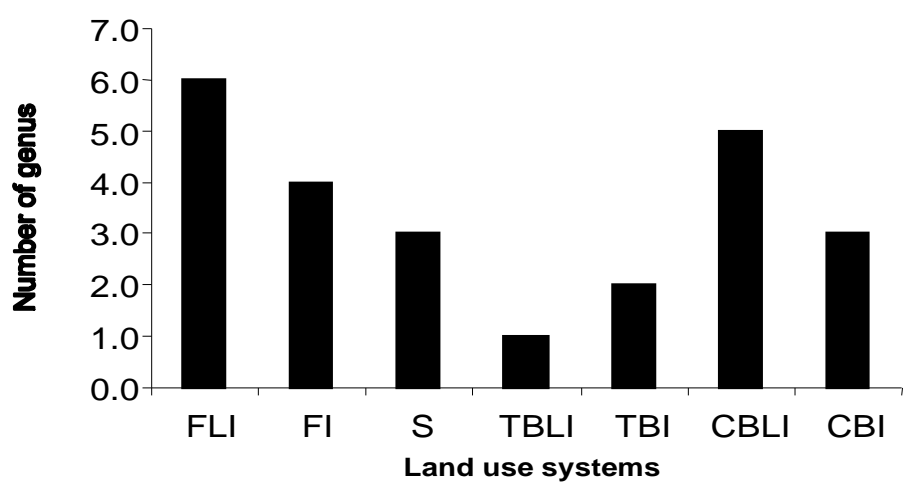

Figure 1. The effect of land use systems on diversity of soil-borne fungal pathogens (FLI=undisturbed forest; FI=disturbed forest; S=shrub; TBLI=shaded/polyculture coffee; TBI=monoculture coffee; CBLI=food crops; $\mathrm{CBI}=$ vegetable/horticulture crop).

of water logged, this condition increase the role of soil-borne pathogens (Burke, 1968).

The number of plant pathogenic fungal genera in food crop was higher than that of in horticulture crop .This was due to the different above-ground vegetation. Food crop system was dominated by cassava and corn and in horticulture crop was dominated by tomato and chili. More fungal problems could be found in field crops while much more viral problems faced in horticultural crops.

\section{Abundance of soil-borne fungal plant pathogens.} The number of viable propagules per gram soil was considered very low in every land-use type. Probably, this result was related to the dry season during October 2004. The soil was dry and the temperature was high enough to suppress the propagules of soilborne pathogens.

The results of the survey also showed that in non agricultural system there was a decline of the abundance of soil-borne pathogenic fungi from forest less intensive to disturbed forest, shrub, and polyculture coffee, but in agricultural system there was an increase from polyculture coffee to monoculture coffee, food crop, and horticulture crop (Figure 2). It seemed that polyculture coffee was the transition area between forest and agriculture land. The decline of fungal abundance in non agricultural system may be due to limited number of fungal host plants in the associated land-uses. The result was also related to the fact that humid forest soils tends to have a high-fungal, low-bacterial content, while highbacterial, low-fungal content soil is very common in an agricultural land. In horticulture crops, dominated by tomato plants, the abundance of soil-borne fungi was as high as in undisturbed forest and a little bit higher than that of in food crops. We observed that at the time of the survey conducted, tomato plants at the surveyed area were severely attacked by fusarium wilt. Therefore, horticulture crop showed a lower diversity but higher abundance of soil-borne pathogenic fungi.

The abundance of the six plant pathogenic fungal genera (Fusarium, Curvularia, Botryodiplodia, Phytophthora, Pythium, and Rhizoctonia) was different in each land-use system. When plotted together with the occurrence of fungal antagonist Trichoderma spp. the population of soil-borne fungal pathogens was lower than that of the antagonist, except for the Fusarium spp.in undisturbed forest and horticulture crop.

Fusarium genus has been recognized as one of soil-borne fungal pathogens economically important because it can be found in almost every land-use and caused high crop loss.

The dynamic of Fusarium genus is very interesting (Figure 3). The pattern of the occurrence of Fusarium spp. was similar to the pattern of soil-borne abundance, except for undisturbed forest. Fusarium spp. is known as polyphage and high in competitive 


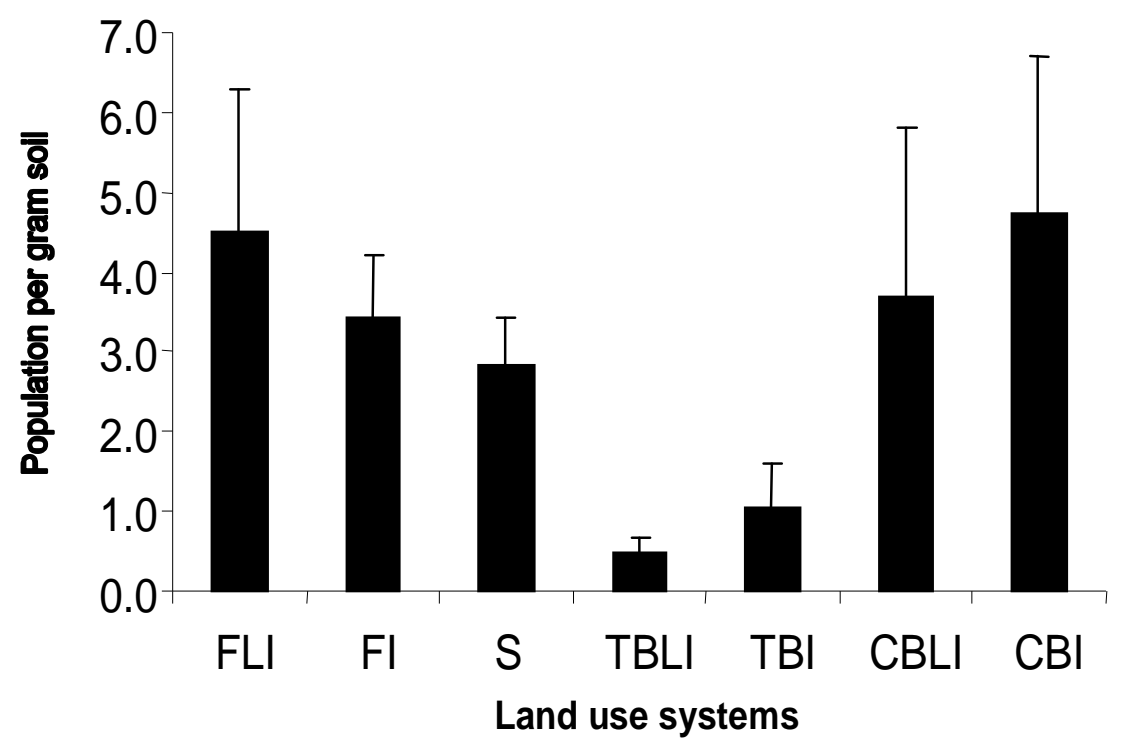

Figure 2. The effect of land use systems on abundance of soil-borne fungal pathogens (FLI=undisturbed forest; FI=disturbed forest; $\mathrm{S}=$ shrub; TBLI=shaded/polyculture coffee; $\mathrm{TBI}=$ monoculture coffee; $\mathrm{CBLI}=$ food crops; $\mathrm{CBI}=$ =vegetable/horticulture crop).

$\diamond$ Fusarium $\square$ Botryo. $\Delta$ Phytoph. $\times$ Pyth. $*$ Curv. $\circ$ Rhizoc. - Trichod.

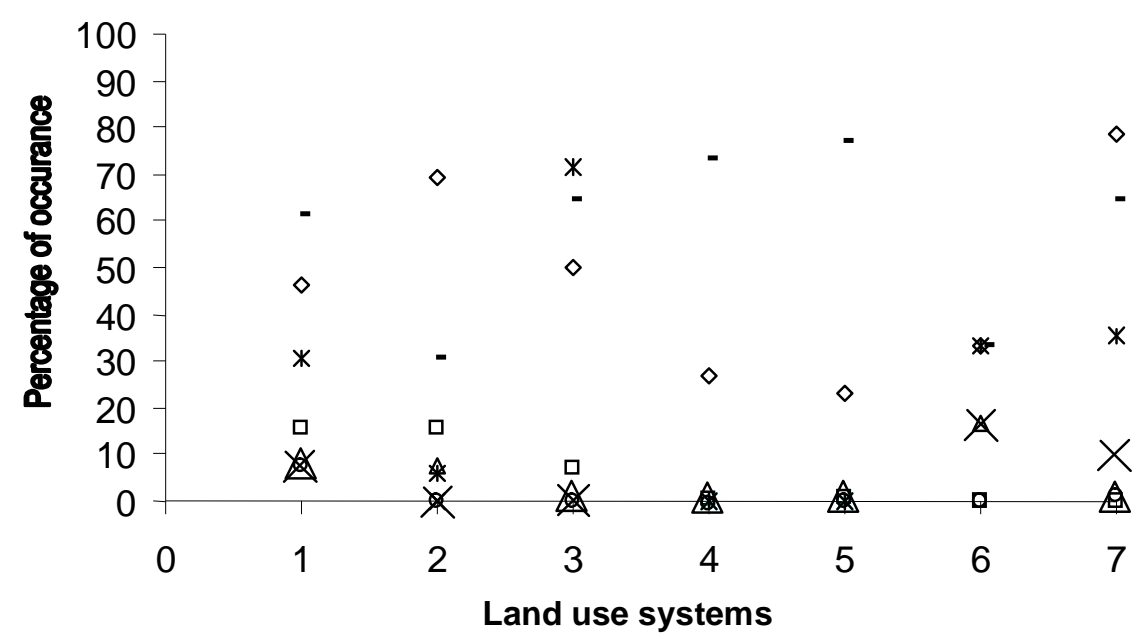

Figure 3. The effect of land use systems on the occurrence of a certain soil-borne fungal pathogen ( $1=\mathrm{FLI}=$ undisturbed forest; $2=\mathrm{FI}=$ disturbed forest; $3=\mathrm{S}=\mathrm{shrub} ; 4=\mathrm{TBLI}=$ shaded/polyculture coffee; $5=\mathrm{TBI}=$ monoculture coffee; $6=\mathrm{CBLI}=$ food crops; $7=\mathrm{CBI}=$ vegetable/horticulture crop). 
saprophytic ability. The low occurrence of Fusarium spp. in tree-based land-use or polyculture and monoculture coffee may due to the high occurrence of Trichoderma spp. (Figure 3).

The dynamic type of Curvularia spp. occurrence is very different from that of Fusarium spp. The occurrence of this fungi was only high on shrub/grass land, while on polyculture and monoculture coffee was zero. Apparently, Curvularia spp. was not readily found in the soil of these land-uses because of the lack of host plants. It is noticed that Curvularia spp. are the pathogen of much kind of grasses around. There was very limited number of grasses in treebased land-use systems.

The occurrence of Botryodiplodia spp. also decreased from undisturbed forest and disturbed forest to the other land uses. With the same argument, it is suspected also that the primary cause is the decrease of host plants. It is noticed that Botryodiplodia spp. are the root pathogens of many forest trees.

The result also indicated that the occurrence of Phytophthora spp. and Pythium spp. were very low (Figure 3), and even did not found in shrub/grassland, polyculture coffee, and monoculture coffee. The absence of Phytopthora spp. and Pythium in shrub, polyculture coffee, and monoculture coffee may be due to the high occurrence of antagonist Trichoderma spp. (Chet \& Baker, 1980) and the absence of their host plants.

Rhizoctonia sp. only occurred in undisturbed forest. It is suspected that the very low occurrence of Rhizoctonia sp. was caused by the high occurrence of fungal antagonist Trichoderma spp. (Chet \& Baker, 1980) in all land use systems.

\section{CONCLUSIONS}

It was concluded that land-use systems had different impacts on diversity and abundance of soilborne pathogenic fungi. The diversity declined in nonagricultural systems from undisturbed forest to disturbed forest, shrub, and polyculture coffee, and then increased in agricultural systems from polyculture coffee to monoculture coffee, and food crop. In horticulture crop, however, the diversity was lower than that of in food crop system. The abundance had a similar trend except for horticulture crop that showed the highest population. Moreover, the percentage of occurrence of soil-borne pathogens was different across land use systems.

\section{ACKNOWLEDGMENTS}

This publication presents part of the findings of the international project "Conservation and Sustainable Management of Below-Ground Biodiversity (CSM-BGBD)" implemented in seven tropical countries - Brazil, Cote d'Ivoire, India, Indonesia, Kenya, Mexico, and Uganda. The project is coordinated by the Tropical Soil Biology and Fertility Institute of CIAT (TSBF-CIAT) with cofinancing from the Global Environment Facility (GEF), and implementation support from the United Nations Environment Program (UNEP).

\section{LITERATURE CITED}

Broadbent, P. \& K.F. Baker. 1974. Association of bacteria with sporangium formation and breakdown of sporangia in Phytophthora spp. Austral. J. Agric. Res. 25: 139.

Burke, D.W. 1968. Root growth obstruction and fusarium root rot of beans. Phytopathology 58: $1575-1576$.

Cambell, C. L. \& L. V. Madden. 1990. Introduction to Plant Disease Epidemiology. John Wiley \& Sons. New York.

Chet, I \& R. Baker. 1980. Induction of suppressiveness to Rhizoctonia solani in soil. Phytopathology 70: 994-998.

Cook, R.J. 1984. Use of pathogen-suppressive soils for disease control, In: Suppressive Soils and Plant Disease (R. W. Schneider, ed.), pp. 511-65. Am. Phytopathol. Soc. St. Paul.

Gillison, A.N., D.T. Jones, F.X. Susilo, \& D.E. Bignell. 2003. Vegetation indicates diversity of soil macro invertebrates: a case study with termites along a land-use intensification gradient in lowland Sumatera. Org. Divers. Evol. 3: 111 - 126.

Mao, W., J.A. Lewis, P.K. Hebar, \& R.D. Lumsden. 1997. Seed treatment with a fungal or a bacterial antagonist for reducing corn damping-off caused by species of Pythium and Fusarium. Plant Disease 81: 454. 
Shurtleff, M.C. \& C.W. Avere III. 1997. The Plant disease clinic and field diagnosis of abiotic diseases. APS Press, St. Paul, Minn.

Schumann, G.L. 1991. Plant Diseases. Their Biology and Social Impact. APS Press. St. Paul, Minn.

Susilo, F.X. \& A. Karyanto. 2005. Methods for Assessment of Below-ground Biodiversity in Indonesia. Universitas Lampung, Bandar Lampung (in press).
Tsao, P.H. 1969. Studies on the saprophytic behavior of Phytophthora parasitica in soil. Proc. First Int. Citrus symp. 3: 1221.

Vincent, J. M. 1970. A Manual for the Practical Study of the Root-nodule Bacteria. International Biological Programme. Burgess and Son (Abingdon) Ltd. Berkshire. 